\title{
LIBERACIÓN
}

$\mathrm{Al}$ alba suspiré por un pelo caído.

Por un pelo caído, de noche suspiré.

Me angustiaba la angustia del desastre final.

¿Quién lo dijera! Calvo, por fin, me siento libre.

Se acabó el peluquero, los tintes y el champú.

Y el peine siempre alerta para ocultar los claros.

$Y$ ya no me despeino cuando hace calor

$\mathrm{y}$ chapoteo en el río fresco de una aljofaina.

Es como otro bautizo: tengo, por fin, la paz

de un monje a rape, libre del pelo y del temor.

\section{LOS FILÓSOFOS}

"De sabios es callar,

los que hablan nada saben"

dicen que dijo Lao Tsé

en un librito de ochocientas páginas. 